\title{
Effects of Type of Wound, Species, and Humidity on Curing of Yam (Dioscorea alata L.) Tubers before Storage ${ }^{1}$
}

\author{
Franklin W. Martin ${ }^{2}$
}

\section{INTRODUCTION}

Scratches, scrapes, and bruises inevitably occur when roots and tubers are harvested. These wounds permit infectious organisms to enter, leading to loss of quality, reduced storage life, or total loss through rotting. Appropriate conditions can permit normal healing processes to take place which reduce this danger. These conditions, however, may not be those optimum for subsequent storage. The post-harvest period thus may be divided into two principal subperiods, curing time and storage time.

Some attention has been given to the storage period of the yam $(D$. alata L.), but almost no information can be found on the special needs during its curing period. During the storage period tubers need shade, cool but not cold temperatures, good ventilation, and moderate humidity. The chief dangers to stored yam tubers are fungal and bacterial rotting, shrivelling, anaerobic breakdown, and premature sprouting. ${ }^{3}$ Unfortunately, no one set of conditions is optimum for avoiding all these normal problems.

Curing, as defined herein, refers to those changes that take place during the first week after harvest tending to prolong the storage life of the tuber. Because most of the degenerative changes are associated with harvest wounds, curing refers chiefly to the healing of wounds during the first week after harvest by controlled but natural processes. The word curing sometimes is used to indicate changes in flavor and composition that accompany storage or special treatment but that particular usage is not under consideration here.

Conditions necessary for curing potatoes and sweetpotatoes are well known. $4^{4} 5$ For the sweetpotato, the optimum temperature is $31^{\circ} \mathrm{C}$, with 80 to 90 percent relative humidity, for about 5 days. Potatoes are cured

1 Manuscript submitted to Editorial Board August 7, 1973.

2 Research Plant Geneticiat, Federal Experiment Station, Agricultural Research Service, U.S. Department of Agriculture, Mayaguiez, P. R.

Coursey, D. G., The magnitude and origins of storage losses in Nigerian yams, J. Sci. Food Agr. 12: 574-80, 1961.

- Ryall, A. L., and Lipton, A. J., Handling, Transportation, and Storage of Fruits and Vegetables, I, Vegetables and Melons, Avi Publishing Co., Westport, Conn., 473 pp., 1972.

S Edmond, J. B., and Ammerman, G. R., Sweet Potatoes; Production Processing, Marketing, Avi Publishing C., Westport, Conn., 344 pp., 1971. 
for 10 to 14 days at a temperature of $7^{\circ}$ to $15^{\circ} \mathrm{C}$, and relative humidity of about 90 percent.

The physiological processes of curing also are well known. In several of the outermost layers of cells near wounds, the process known as suberization occurs. This includes a conversion of starch to unsaturated fatty acids and the oxidation of these to form suberin, a compound that impedes further water loss from the cut surface. In addition, certain of the parenchymatous cells somewhat deeper than the suberized layer are modified to form a new meristem. Through the multiplication of these cells, a new cork layer is formed, and thus the wound can be considered cured.

\section{MATERIALS AND METHODS}

For this study, harvested yams of representative species and varieties were observed to determine the types of wound that normally occur. The wounds then were classified as follows, and reproduced by the technique mentioned:

Severing: Clean cross-sections cut with a knife.

Deep cutting: Knife used to produce deep internal cuts.

Scraping: Irregular superficial scrapes produced by rubbing the tuber on a rough surface.

Bruising: Produced by hammer blows.

Tubers injured (as above) were placed in relatively dry and relatively moist atmospheres in the laboratory at ambient temperatures of about $26^{\circ}$ to $28^{\circ} \mathrm{C}$. Several tubers were protected by covering the wounded surface with paper, plastic, cellophane, wax, fungicide, wood ashes, or treating the surface for 5 minutes with 95-percent ethanol. Deteriorative changes were observed for 2 weeks and rated on a scale of 0 (none) to 3 (severe).

Small tubers of $D$. alata L. var. Morado were wounded as described and treated for 1 week at one temperature with three levels of humidity maintained as follows:

1. Dry-Exposed to the relatively dry air of the laboratory.

2. Intermediate-Protected from excess drying by paper bags.

3. Humid-Maintained in closed glass jars with small containers of water.

Five tubers were used for each wound-curing treatment combination and for controls. After 1 week, all of the yam tubers were exposed to the same conditions, the relatively dry air of the laboratory. Observations were made of the deterioration that had taken place. The tubers were weighed each week for a total of 8 weeks after treatments were begun.

Aerial tubers of $D$. bulbifera, a species that drops its tubers to the ground when they mature, were wounded by the same methods. The curing treat- 
ments given were as follows:

1. Dry, medium temperature-Exposed to the relatively dry air of the laboratory.

2. Humid, medium temperature-Maintained in closed glass jars with small containers of water.

3. Medium humidity, cold-Stored in paper bags in the refrigerator one week.

4. Medium humidity, hot-Exposed to the sun as if on the soil for 1 week.

Five tubers were used for each wounding and curing treatment, and for controls. After 1 week, all tubers were exposed to the relatively dry air of the laboratory, where they were observed for moisture loss and deterioration for 5 weeks.

\section{RESULTS}

\section{OBSERVATION OF WOUNDS}

Typical wounds were observed in $D$. alata L., $D$. rotundata Poir, $D$. esculenta (L.) Birk., and D. bulbifera L. The first result of the injury to the yam tuber is the release of fluids. The fluid that covers the injured surface is rich in mucilaginous gums, apparently protein. Phenolic substances and phenolases apparently are also released, for the surface is rapidly oxidized to a brown color. When the surface is covered immediately with transparent plastic, such discoloration does not occur. However, tubers of some varieties do not discolor when cut, possibly because either the enzymes or the phenolic substances are absent, or the enzymes are inhibited.

If the cut surfaces are exposed to dry air, they can eventually dry. During drying, a cap of dead, desiccated cells forms over the cut surface. As the surface continues to dry, the yam shrivels, particularly near the lesion. Although some fungal growth may be associated with the dry cap of dead cells protecting the cut surface, this usually leads only to mild discoloration of the sound tissue below. Cracks often appear parallel to the grain of the yam. As these grow, fresh surfaces are exposed to the air, opportunities for entry of fungi are increased, and fungal rot usually begins.

If cut surfaces are not exposed to the open air, they dry very slowly. Fungi then have an opportunity to attack and, once established, gradually destroy large amounts of tissue.

In superficial scrapes, healing occurs rapidly. Although a cambial layer is found in the cortex, there does not appear to be a growth of new tissue to protect the wound. Deep cuts do not heal, but often do not lead to deterioration of the yam tuber. Bruises lead to internal discoloration. If associated with open cuts, bruised tissue rots rapidly. 
Species and varieties with dense, compact tissue (D. esculenta, some varieties of $D$. alata) heal more readily than those with less dense tissues. Cut surfaces dry more rapidly, and cracking is much less likely to occur. In one species, $D$. bulbifera, the tissue below the wound is impregnated with a brown compound, probably suberin, which very effectively reduces further moisture loss.

\section{PROTECTION OF CUT SURFACES}

This study was made with tubers of $D$. esculenta and confirmed with a few samples of $D$. alata. Covering the cut surface of a damaged yam tuber may give three kinds of protection; from air, from fungi, and from light.

TABLe 1.-Deteriorative changes' in yam tubers (Dioscorea esculenta) associated with treatment of cul surfaces after 1 week

\begin{tabular}{lllllc}
\hline \multicolumn{1}{c}{ Treatment of cut surface } & $\begin{array}{c}\text { Discolora- } \\
\text { tion }\end{array}$ & Shriveling & $\begin{array}{c}\text { Mold } \\
\text { 8rowth }\end{array}$ & $\begin{array}{c}\text { Discolora- } \\
\text { tion }\end{array}$ & $\begin{array}{c}\text { Thickness } \\
\text { of dead } \\
\text { cell cap } \\
\text { (mm) }\end{array}$ \\
\hline None & 2 & 2.5 & 1 & 0 & 1.5 \\
Dry air & 2 & 3 & 0 & 0 & 2.0 \\
Humid air & 3 & 0 & 2 & 1 & \\
Surface treatment 95\% & 2 & 3 & 1 & 0 & 1.0 \\
Covered, paper towels & 3 & 2 & 0 & 0 & 1.0 \\
Covered, cellophane & 1 & 0 & 0 & 0 & 0.1 \\
Covered, polyethylene plastic & 1 & 0 & 0 & 0 & 0.1 \\
Covered, paraffin & 1 & 1 & 0 & 0 & 0.1 \\
Dusted, fungicide & 2 & 3 & 1 & 1 & 1.5 \\
Dusted, ashes & 2 & 2 & 0 & 0 & 1.0 \\
\hline
\end{tabular}

1 Rated 0-3 on basis of intensity.

For example, when cut surfaces were covered with paper toweling, moisture was still exchanged, some shrivelling occurred, a thin layer of dead cells was formed, and mold growth was impeded (table 1). When an impermeable cover was used, such as plastic cloth, cellophane, or paraffin, water loss was drastically reduced, shrivelling was insignificant, polyphenolic discoloration was minimized, and the layer of dead cells was very thin. If the cover permitted light to enter, chlorophyll sometimes developed in the parenchymatous tissue, especially near the cortex.

Fungicidal dust on the treated surface did not reduce fungus growth. In fact, the toxicity of such substances to healthy tissue might have increased mold damage in some cases. The milder treatment of dusting with woodashes, a common treatment of wounded yam tubers, offered some protection from molds and evaporation. Treatment with 95-percent alcohol did not affect any of the characteristics observed. 
Tubers of $D$. alata, wounded by four methods and treated at three levels of humidity, differed 1 week after treatment in quality and in state of deterioration, obviously influenced by the wounding-curing combination. In all tests, tubers lost less weight in the humid chamber than in paper bags or when exposed to open air (table 2). However, all the open wounded surfaces were covered with fungal growths. Deep cuts had apparently healed in some tubers.

In contrast, the wounded surfaces of tubers exposed to the open air were almost free of fungi. Only wounds that involved cracks were infected. Bruises were beginning to soften in some instances, although infection was not obvious. The tubers in open air lost more weight during curing than

TABLE 2.-Percenlage of weight lost by wounded yam tubers, variety Morado, during curing and afler 8 weeks of storage

\begin{tabular}{llrrrr}
\hline \multirow{2}{*}{ Type of wounding } & Time of observation & \multicolumn{3}{c}{ Curing conditions } & \\
\cline { 3 - 6 } & & $\begin{array}{c}\text { Open } \\
\text { air }\end{array}$ & $\begin{array}{c}\text { Paper } \\
\text { bag }\end{array}$ & $\begin{array}{c}\text { Humid } \\
\text { cham- } \\
\text { ber }\end{array}$ & Averages \\
\hline \multirow{2}{*}{ Severing } & After curing & 10 & 9 & 5 & 7 \\
Deep cuts & After storage & 17 & 22 & 21 & 20 \\
Superficial abrasions & After curing & 5 & 6 & 3 & 5 \\
Bruising & After storage & 22 & 23 & 17 & 21 \\
& After curing & 8 & 6 & 3 & 6 \\
Control & After storage & 24 & 15 & 14 & 18 \\
& After curing & 5 & 6 & 4 & 5 \\
& After storage & 18 & 19 & 21 & 19 \\
& After curing & 4 & 3 & 1 & 3 \\
\hline
\end{tabular}

did those in bags or in the humid chamber. Tubers in bags were intermediate. In all bags, some fungal growth had begun, but weight loss was not excessive.

After 8 weeks of storage, the situation had changed. Weight loss and deterioration depended on the combination of wounding and curing treatments. Tubers with superficial scrapes and cuts, or with deep cuts did not lose as much weight if cured in the humid chamber as tubers that were exposed to open air. Humid conditions permitted infection with fungi and then infections continued at a slow rate during the storage period. When the damaged area was more extensive, as in the case of severed tuber pieces, initially more weight was lost by dry-air curing but subsequently an even greater amount of moisture was lost from the pieces cured in humid air because of the rapidly invading fungal growths.

Deep cuts were apparently healed by dry-air treatments but when the 
tubers were opened after storage deep pockets of rot were found. Damage was even more extensive in tubers cured in humid air; the deep cuts had opened and rot was extensive. Bruises led to severe rots in all tubers and no differences associated with curing treatments could be seen.

Aerial tubers of $D$. bulbifera healed more rapidly than underground tubers of $D$. alata. Much less rotting occurred and wounds appeared well protected by a suberized layer of cells.

Exposure to the sun damaged the tubers. Even the nonwounded controls lost weight rapidly and began to rot when subsequently stored (table 3). Leaving tubers in the sun after harvest is thus a bad practice. Cool temperatures of the refrigerator inhibited curing of wound later and water

TABLE 3.-Percentage loss of weight of aerial tubers of $\mathbf{D}$. bulbifera after 1 week of treatment and 5 additional weelss of storage as affected by treatment and type of wound

\begin{tabular}{|c|c|c|c|c|c|c|}
\hline Treatment & Observation & Controls & $\begin{array}{l}\text { Super- } \\
\text { fcial } \\
\text { scrapes }\end{array}$ & $\begin{array}{c}\text { Deep } \\
\text { cuts }\end{array}$ & $\begin{array}{c}\text { Severed } \\
\text { parts }\end{array}$ & Bruises \\
\hline \multirow[t]{2}{*}{ Exposed to sun } & After treatment & 8 & 22 & 53 & 27 & 40 \\
\hline & After storage & 31 & 39 & 57 & 48 & 76 \\
\hline \multirow{2}{*}{$\begin{array}{l}\text { Household refrig- } \\
\text { erator }\end{array}$} & After treatment & 2 & 11 & 4 & 14 & 10 \\
\hline & After storage & 4 & 33 & 14 & 34 & 31 \\
\hline \multirow{2}{*}{$\begin{array}{l}\text { Open air of labora- } \\
\text { tory }\end{array}$} & After treatment & 2 & 8 & 3 & 8 & 7 \\
\hline & After storage & 6 & 14 & 7 & 12 & 13 \\
\hline \multirow{2}{*}{$\begin{array}{l}\text { Humid chamber of } \\
\text { laboratory }\end{array}$} & After treatment & 0.4 & 2 & 0.6 & 0.6 & 0.7 \\
\hline & After storage & 3 & 8 & 4 & 8 & 8 \\
\hline
\end{tabular}

loss was excessive from the wounded tubers, but this treatment did not damage the control tubers.

In contrast to the results with $D$. alata, aerial tubers of $D$. bulbifera benefited more from the humid than from the dry treatment. All wounds appeared to heal very well and were free from fungal infections. More shrivelling and weight loss occurred in the tubers cured in dry air.

\section{DISCUSSION}

These simple experiments suggest that the rate of deterioration of yam tubers in storage is influenced by type of wounds received at harvest, treatment received during the first week after harvest, and species and varietal differences. As a general rule, superficial abrasions are easily cured, severed surfaces can be cured, and deep cuts and bruises never completely cure. Fungi rapidly invaded wounds and seemed to be the chief source of loss. However, weight loss, partly caused by loss of water, may also be a problem. 
All yam tubers should be removed from the sun as rapidly as possible after harvest. If the tubers are not sensitive to fungi, they can best be cured at a high humidity. If, as in most species, fungi can be a problem, a low humidity is more desirable because it permits a protective cap of dead cells to form. However, if the dry treatment is excessive, cracking can increase the severity of the wound and the danger from fungal infection. Cold temperatures are not desirable during the curing period, even though they may be useful during subsequent storage.

In contrast to the curing of potato and sweetpotato, the curing of yam tubers does not involve the production of a new phelloderm. In D. bulbifera, a suberized layer of cells forms. This, and perhaps secondary substances of the tuber, protects against mold formation. In most yam tubers, curing consists of the development of a thin layer of dried dead cells on the surface of wounds, which mechanically retards water loss and fungal infection.

From these observations, appropriate experiments on curing of yam can be devised.

\section{SUMMARY}

The first week after yam tubers were harvested, conditions of humidity, temperature, and treatment influenced the curing of wounds, the degree of fungus infection, and subsequent moisture loss and breakdown in storage. Certain kinds of wounds, including bruises and deep cuts, are difficult to heal and are not very much affected by treatments. On the other hand, superficial scrapes are best cured in dry air. Cut surfaces can best be cured by drying, but extensive drying causes cracking, which permits fungal infection. Although humid air reduces water loss, it also encourages the growth of fungi. Curing does not involve wound periderm formation, but suberization of wounded surfaces provides ample protection in some varieties. The principal needs of wounded yam tubers during the curing period are restriction of water loss and inhibition of fungal infection. These are contradictory and it may be that curing conditions must be selected as compromises between extremes.

\section{RESUMEN}

Durante la primera semana después de que se cosechan los tubérculos del ñame tales condiciones como la humedad, la temperatura y ciertos tratamientos influyen sobre la curación de las lesiones sufridas, el grado de infección causada por los hongos y la pérdida de agua y pudrición subsiguientes durante el almacenamiento. Ciertas lesiones, incluyendo contusiones y cortes profundos, son difíciles de curar y poco afectadas por los tratamientos. Por otra parte, las raspaduras se curan mejor con aire seco. Si el período del secado se extiende demasiado, se forman hendiduras que permiten de nuevo el acceso de hongos. Aunque el aire húmedo reduce la pérdida de agua, también promueve el crecimiento de hongos. En ningún caso hubo una nueva 


\section{JOURNAL OF AGRICULTURE OF UNIVERSITY OF PUERTO RICO}

formación peridérmica, pero la suberización de las superficies lesionadas provee amplia protección en algunos casos. Definitivamente los resultados sugieren que las necesidades principales de los tubérculos de ñame lesionados durante el período de curación, o sea la restricción en la pérdida de humedad y la evitación de que crezcan los hongos, son contradictorias. Parece ser que al seleccionarse las condiciones ideales para la curación deben evitarse ambos extremos. 